\title{
Chronic postsurgical pain: still a neglected topic?
}

This article was published in the following Dove Press journal:

Journal of Pain Research

3 November 2012

Number of times this article has been viewed

Igor Kissin

Simon Gelman

Department of Anesthesiology, Perioperative and Pain Medicine, Brigham and Women's Hospital, Harvard Medical School, Boston, MA, USA
Correspondence: Igor Kissin Brigham and Women's Hospital, 75 Francis Street, MRB 6II, Boston, MA 021।5, USA

Tel +l 6177325052

Fax +I 6177340682

Email kissin@zeus.bwh.harvard.edu
Background: Surgical injury can frequently lead to chronic pain. Despite the obvious importance of this problem, the first publications on chronic pain after surgery as a general topic appeared only a decade ago. This study tests the hypothesis that chronic postsurgical pain was, and still is, represented insufficiently.

Methods: We analyzed the presentation of this topic in journal articles covered by PubMed and in surgical textbooks. The following signs of insufficient representation in journal articles were used: (1) the lack of journal editorials on chronic pain after surgery, (2) the lack of journal articles with titles clearly indicating that they are devoted to chronic postsurgical pain, and (3) the insufficient representation of chronic postsurgical pain in the top surgical journals.

Results: It was demonstrated that insufficient representation of this topic existed in 1981-2000, especially in surgical journals and textbooks. Interest in this topic began to increase, however, mostly regarding one specific surgery: herniorrhaphy. It is important that the change in the attitude toward chronic postsurgical pain spreads to other groups of surgeries.

Conclusion: Chronic postsurgical pain is still a neglected topic, except for pain after herniorrhaphy. The change in the attitude toward chronic postsurgical pain is the important first step in the approach to this problem.

Keywords: neuropathic pain, persistent pain, chronic pain, postoperative pain

\section{Introduction}

The recent report of the Institute of Medicine's committee on pain relief in the US indicated that "more than 116 million Americans have pain that persists for weeks to years." The important part of this problem is chronic postsurgical pain. Aasvang and Kehlet ${ }^{2}$ estimated the incidence of chronic pain after some surgical procedures: thoracotomy (approximately 50\%), breast surgery (30\%), cholecystectomy $(10 \%-20 \%)$, and inguinal herniorrhaphy $(10 \%)$. When the total number of patients who undergo these surgeries each year is taken into account, those figures are stunning. Macrae ${ }^{3}$ tried to present some figures that reflect the magnitude of the chronic postsurgical pain problem. His calculations yielded at least 400,000 new cases of chronic pain each year (in the US). He also indicated ${ }^{4}$ that about $20 \%$ of patients attending chronic pain clinics name surgery as one of the causes of their chronic pain, and for about half of these patients it was the sole cause.

Despite the obvious importance of this problem, publications on chronic pain after surgery as a general topic began to appear only a decade ago. ${ }^{46}$ These authors analyzed more than 100 references related to chronic postsurgical pain, noting that several features were common to all publications: (1) they were strictly limited to specific 
operations, (2) they failed to give a detailed description of the operative approaches, and (3) they usually provided only superficial assessments of chronic pain. ${ }^{4,6}$ Their conclusion was that "chronic pain after surgery has been a neglected topic." 4

The word "postsurgical" in the term "chronic postsurgical pain" already indicates the role of surgery in its genesis. The combination of two factors related to coping with this problem gives surgery an additional importance: (1) ineffective existing treatments of neuropathic pain and (2) the importance of surgical techniques avoiding nerve injuries in the prevention of this type of chronic pain. Unfortunately, treatments for neuropathic pain, including the majority of chronic postsurgical pain cases, are not very effective. No more than $40 \%-60 \%$ of patients obtain pain relief; in addition, the relief is only partial. ${ }^{7}$ Existing evidence indicates that intraoperative nerve injury is the most important contributor to the development of chronic postsurgical pain. ${ }^{8,9}$ The analysis of all possible approaches for the prevention of postsurgical pain points to one reliable solution: surgical techniques that avoid nerve damage should be used wherever possible. ${ }^{8}$ As a result, although chronic postsurgical pain is a topic relevant to many specialties (surgery, anesthesiology, neurology, pain medicine, rehabilitation medicine, and psychology), currently, the most promising approach to reducing the incidence and intensity of chronic postsurgical pain is almost completely in the hands of surgeons, who can select techniques that minimize the risk of nerve damage. Therefore, the adequate presentation of chronic postoperative pain in surgical journals and textbooks is especially important.

Our study tested the hypothesis that chronic pain after surgery was, and still is, represented insufficiently. We analyzed the presentation of this topic in journal articles covered by PubMed, especially in surgical journals, and also in surgery textbooks.

\section{Methods}

To test the study hypothesis with journal articles, we used the following three signs of insufficient representation: (1) the lack of journal editorials on chronic pain after surgery, (2) the lack of journal articles with titles clearly indicating that they are devoted to chronic postsurgical pain, and (3) the insufficient representation of chronic postsurgical pain in the top surgical journals. Concerning the analysis of textbooks, we followed the general approach used by Rabow et al. ${ }^{10}$ The representation of chronic postsurgical pain in textbooks was assessed on the basis of the presence of this topic in general chapters and in the chapters on specific surgeries, as well as on the total content volume related to chronic pain after surgery. Journal articles were collected using the National Library of Medicine's PubMed website (http://www.ncbi. nlm.nih.gov/PubMed). All types of articles published in English during 30 years (1981-2010) were included. Keywords related to the names of surgical interventions were added to the terms related to the chronic pain ("chronic pain" OR "neuropathy" OR "neuralgia"). Boolean operations were used in which the following variables were selected: keywords, years of publications, and type of publications. In addition to the electronic search of articles, related publications were also collected manually from the literature on chronic postsurgical pain (Figure 1).

\section{Editorials}

The editorials (articles solicited by an editorial board to provide an editorial perspective on the article published in a journal) on chronic postsurgical pain were grouped into 5-year periods, starting with 1981-1985, separately for (1) all journals covered by PubMed and (2) only surgical journals.

\section{Topic-in-title articles}

To select journal articles with titles clearly indicating that they are devoted to chronic postsurgical pain (topic-in-title articles), the indication "[Title]" was added to all terms placed into PubMed search boxes. The topic-in-title type of articles were searched as representing chronic pain after surgery in general (when terms "surgery" [Title] OR "postoperative" [Title] were added to pain terms "chronic pain" [Title] OR "neuropathy" [Title]) or as representing chronic pain after specific surgeries (see Table 1). The specific surgeries were selected on the basis of preliminary PubMed searches conducted with inclusion of various specific terms of surgical interventions and specific pain-related terms (indicated in Table 1). In the preliminary searches, the indication "[Title]" in the PubMed search box was not used. The preliminary searches resulted in a total of 1043 references. The topic-in-title articles for a specific group of surgeries were counted only when a preliminary search for this group gave ten or more general (non-topic-in-title) references. Eight groups of surgeries were selected: herniorrhaphy, limb amputation, thoracic surgery, arthroplasty, breast surgery, cardiac surgery, gallbladder surgery, and prostatectomy. For inclusion as the topic-in-title publication, articles found in various searches were reviewed to make sure that they fit the definition of chronic pain after surgery. Articles with titles without certain indication of pain duration, such as 


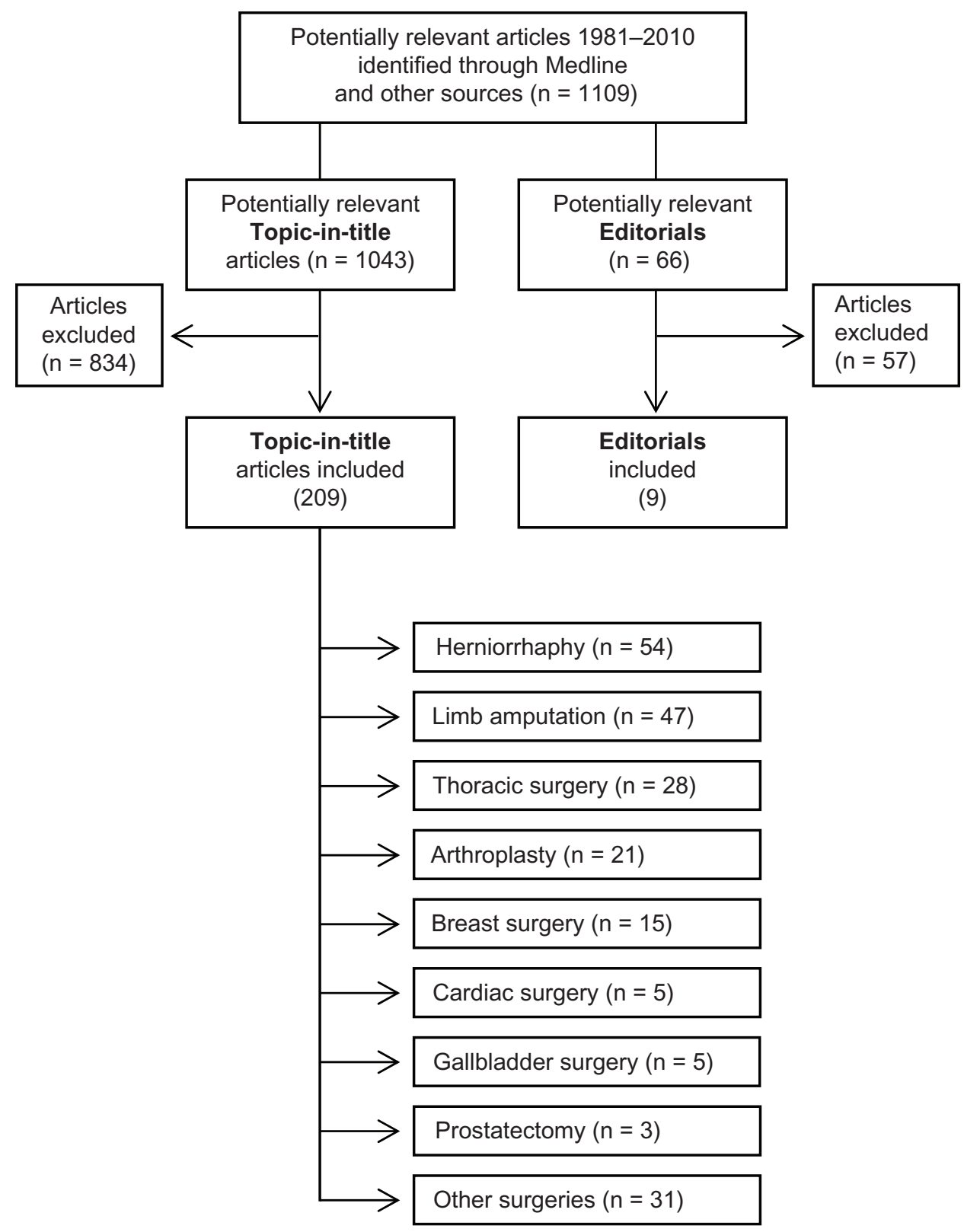

Figure I Flow chart of screened, excluded, and included articles on chronic postsurgical pain (I98I-20I0).

"persistent," "persisting," "long-term," "residual pain," or "pain syndrome" were checked and included only if the duration of pain was 6 months or longer. If the duration of pain was indicated in the title of an article as 6 months or longer, it was also included in the database.

To quantitatively evaluate the response of surgical journals to the problem of chronic postsurgical pain, we analyzed the publications of topic-in-title articles in the top 20 surgical journals. It has been observed that the number of journal articles on a new and important topic rises much faster in the top specialty journals than it does in all other journals covered by PubMed. ${ }^{11}$ We also calculated the Top Journal Selectivity
Index (TJSI). This index represents the ratio of the number of articles in the top 20 surgical journals to the number of articles in all journals covered by PubMed ${ }^{11,12}$ (see Discussion). We counted only articles with titles clearly announcing that they are devoted to chronic pain after surgery (topic-in-title articles). The selection of the top 20 surgical journals was based on the rank of a journal sorted by the impact factor, as indicated by Journal Citation Reports for year 2010 (http://science.thomsonreuters.com). The following surgical journals were included: the American Journal of Surgery, American Journal of Surgical Pathology, American Journal of Transplantation, Annals of Surgery, Annals of Surgical 
Table I Numerical representation of topic-in-title articles on chronic pain after specific surgeries, $1981-2010^{a}$

\begin{tabular}{|c|c|c|}
\hline No & Terms of surgical interventions ${ }^{b}$ & $\begin{array}{l}\text { Number of topic-in- } \\
\text { title articles }\end{array}$ \\
\hline $\mathrm{I}$ & Herniorrhaphy OR "hernia repair" & 54 \\
\hline 2 & Amputation ${ }^{c}$ & 47 \\
\hline 3 & "Thoracic surgery" OR thoracotomy & 28 \\
\hline \multirow[t]{2}{*}{4} & Arthroplasty OR "knee replacement" & 21 \\
\hline & OR "hip replacement" & \\
\hline 5 & $\begin{array}{l}\text { "Breast surgery" OR "breast } \\
\text { reconstruction" OR mastectomy }\end{array}$ & 15 \\
\hline 6 & $\begin{array}{l}\text { "Cardiac surgery" OR } \\
\text { "CABG surgery" OR sternotomy }\end{array}$ & 13 \\
\hline 7 & $\begin{array}{l}\text { "Gallbladder surgery" OR } \\
\text { cholecystectomy }\end{array}$ & 5 \\
\hline 8 & Prostatectomy & 3 \\
\hline Total & & 186 \\
\hline $\begin{array}{l}\text { Notes } \\
\text { postsur } \\
\text { "neuro } \\
\text { "residu }\end{array}$ & $\begin{array}{l}\text { "Electronic (via PubMed) and manual search } \\
\text { ical pain. "AND the following pain-relatec } \\
\text { thy" OR "neuralgia" were added. 'the follow }\end{array}$ & $\begin{array}{l}\text { of the literature on chronic } \\
\text { terms: "chronic pain" OR } \\
\text { g terms: "phantom pain" OR } \\
\text { ms. }\end{array}$ \\
\hline
\end{tabular}

Oncology, Archives of Surgery, British Journal of Surgery, Dermatologic Surgery, Endoscopy, Journal of the American Academy of Orthopaedic Surgeons, American Journal of Bone and Joint Surgery, Journal of Gastrointestinal Surgery, Journal of Shoulder and Elbow Surgery, Journal of Surgical Oncology, Journal of Vascular Surgery, Journal of Thoracic and Cardiovascular Surgery, Surgical Endoscopy, Surgery, Transplantation, and World Journal of Surgery.

\section{Textbooks}

The assessment of representation of chronic postsurgical pain in the surgical textbooks was based on the analysis of three texts selected on the basis of two factors: the text should be eponymously titled (named texts) and also should be sorted as one of the top three surgical texts held in libraries as listed in the meta-catalog WorldCat (worldcat.org). The following textbooks were selected: Sabiston Textbook of Surgery, 18th ed, 2008; ${ }^{13}$ Schwartz's Principles of Surgery, 9th ed, $2009 ;{ }^{14}$ and Greenfield's Surgery, 5th ed, 2010. ${ }^{15}$ For comparison, an anesthesiology textbook was also analyzed: Miller's Anesthesia, 7th ed, 2010. ${ }^{16}$ All textbooks were inspected on the presence of materials related to chronic postsurgical pain (number of lines of text, tables, figures, references). The data were collected in three steps: (1) review of chapters on basic principles (examination of the table of contents, identification of chapters devoted to general topics, inspection of all pages of identified chapters), (2) review of specific surgeries (examination of text index for keywords concerning specific surgeries: limb amputation, thoracotomy, coronary artery bypass grafting, mastectomy, cholecystectomy, herniorrhaphy, and arthroplasty; inspection of all pages of identified chapters), and (3) examination of the text index (keywords concerning specific chronic pain syndromes: causalgia, complex regional pain syndrome, neuralgia, neuropathy, pain chronic, pain neuropathic, phantom pain; inspection of all pages indicated for these terms.) Each textbook was assessed by two reviewers (SG and IK). Discrepancies in the count were resolved by consensus.

\section{Results \\ Editorials}

The results on the representation of chronic postsurgical pain in journal editorials are presented in Table 2. Since 1981 only nine editorials were published (two in 2001-2005 and seven in 2006-2010). Seven of them appeared in anesthesiological journals (four in Anesthesiology) and none in surgical journals.

\section{Topic-in-title articles}

Topic-in-title articles (clearly announcing the problem of chronic postsurgical pain) are presented in Table 3. This table reflects only the number of articles that represent chronic pain after surgery in general. It indicates that the topic-in-title articles began to appear in significant numbers only relatively late, especially in surgical journals (2001-2010). Table 4 compares the numbers of topic-in-title articles on chronic and acute postsurgical pain represented as a percentage of all articles on chronic or acute pain (without the indication "surgery" and "postoperative"). The percentage of the topicin-title type of articles on chronic postsurgical pain was $0 \%$ in 1981-1990 and rose to $0.8 \%$ in 2001-2010. Nevertheless, even in 2001-2010 it was one-seventh the number on acute postsurgical pain.

The summary of the results with the topic-in-title articles for eight specific groups of surgeries is presented in Table 1. The most publications were on herniorrhaphy (54 articles), then, in decreasing order, amputation (47),

Table 2 Editorials on chronic postsurgical pain

\begin{tabular}{llll}
\hline Years & \multicolumn{2}{l}{ Number of editorials } & References \\
\cline { 2 - 3 } & All journals & Surgical journals & \\
\hline $8 I-85$ & 0 & 0 & \\
$86-90$ & 0 & 0 & \\
$91-95$ & 0 & 0 & \\
$96-00$ & 0 & 0 & 22,23 \\
$0 I-05$ & 2 & 0 & $24-30$ \\
$06-10$ & 7 & 0 & \\
\hline
\end{tabular}


Table 3 Topic-in-title articles on chronic postsurgical pain, $198 \mid-2010$

\begin{tabular}{lll}
\hline Years & \multicolumn{2}{l}{ Numbers of articles $^{\mathbf{a}}$} \\
\cline { 2 - 3 } & All journals $^{\mathbf{b}}$ & Surgical journals $^{\text {jul }}$ \\
\hline $81-85$ & 0 & 0 \\
$86-90$ & 0 & 0 \\
$91-95$ & 2 & 2 \\
$96-00$ & 9 & 2 \\
$01-05$ & 15 & 6 \\
$06-10$ & 31 & 10 \\
\hline
\end{tabular}

Notes: aAticles with titles clearly indicating that they are devoted to postsurgical chronic pain. Searched as articles on chronic pain after surgery in general: "chronic pain" OR "neuropathic" AND "surgery" OR "postoperative;" bincluding surgical journals.

thoracic surgery (28), arthroplasty (21), breast surgery (15), and cardiac surgery (13). There were only five topic-in-title articles on gallbladder surgery and three on prostatectomy. The distribution of articles among journals of different specialties depended on the type of specific surgeries. With herniorrhaphy it was mostly surgical journals, with limb amputation mostly pain journals and disability/rehabilitation journals, and with all other surgeries mostly anesthesiology and pain journals. Table 5 presents the time-related progress in numerical representation of topic-in-title articles on chronic pain after specific surgeries in all journals and separately in all surgical journals. In surgical journals the only impressive rise was for herniorrhaphy, from five articles in 1991-2000 to 41 in 2001-2010.

The publication of topic-in-title articles on chronic pain after surgery in the top 20 surgical journals is represented in Table 6. In 1991-2000 only two articles were published in the top surgical journals, but that dramatically increased (to 18) in 2001-2010. The TJSI calculated for herniorrhaphy (only for topic-in-title articles) was $36.7 \%$ in $2001-2010$. That means that these articles published in the top 20 surgical journals constitute almost one-third of all articles published

Table 4 Comparisons of topic-in-title articles on chronic and acute postsurgical pain

\begin{tabular}{|c|c|c|c|c|}
\hline \multirow[t]{2}{*}{ Years } & \multicolumn{2}{|c|}{$\begin{array}{l}\text { “Chronic pain”a AND } \\
\text { “surgery"b IN TITLE }\end{array}$} & \multicolumn{2}{|c|}{$\begin{array}{l}\text { "Pain" NOT “chronic" } \\
\text { AND “surgery"b } \\
\text { INTITLE }\end{array}$} \\
\hline & $\begin{array}{l}\text { Number } \\
\text { of articles }\end{array}$ & $\begin{array}{l}\text { As a } \\
\text { percentage } \\
\text { of "chronic } \\
\text { pain"a onlyc }\end{array}$ & $\begin{array}{l}\text { Number } \\
\text { of articles }\end{array}$ & $\begin{array}{l}\text { As a } \\
\text { percentage } \\
\text { of "pain" } \\
\text { onlyc }\end{array}$ \\
\hline $81-90$ & 0 & $0 \%$ & 626 & $6.8 \%$ \\
\hline $91-00$ & II & $0.6 \%$ & 1137 & $6.5 \%$ \\
\hline $0 \mathrm{I}-10$ & 46 & $0.8 \%$ & 2117 & $5.8 \%$ \\
\hline
\end{tabular}

in journals covered by PubMed ( $>5000)$. However, the same index for the other seven surgeries was only $2.9 \%$.

\section{Textbooks}

The textbook analysis is presented in Table 7. Only chronic pain after inguinal herniorrhaphy was present in all three surgical texts (but not in Miller's Anesthesia). Greenfield's Surgery mentioned chronic pain after three specific surgeries (more than the other texts in this regard); however, it did not include anything on chronic postsurgical pain in the chapters on basic principles. Orthopedic surgeries in general were included only in one of the three surgical texts; therefore, chronic pain after arthroplasty is not in the table. The number of chronic pain-related references varied from two to five in the surgical texts, and there were 12 references in Miller's Anesthesia. The chronic pain-related figures or tables were absent in Sabiston Textbook of Surgery and Greenfield's Surgery. There were two chronic pain-related tables in Schwartz's Principles of Surgery. Miller's Anesthesia included two figures and two tables related to chronic postsurgical pain. The total number of lines on chronic postsurgical pain was more or less similar: from 85 to 64 lines in the surgical texts and 100 lines in Miller's Anesthesia. Taking into account that one page of the texts has approximately 120 lines and the total volume of the texts varies from 2000 to 3000 pages, the presentation of chronic pain after surgeries is almost negligible.

\section{Discussion}

The indices that were used in this study indicated that the topic of chronic postsurgical pain is represented insufficiently, especially in surgical journals. Only nine editorials on chronic postsurgical pain were published in 1981-2010, all in nonsurgical journals. The articles clearly announcing the problem of chronic postsurgical pain (topic-in-title articles) began to appear in significant numbers only relatively late, in 2001-2010; however, even during the last decade they were sevenfold fewer than articles on acute postsurgical pain. In 1991-2000 only two topic-in-title articles on chronic pain after surgery were published in the top 20 surgical journals. There was a clear sign that the interest in chronic postsurgical pain began to increase in 2001-2010, but only in one group of surgeries: herniorrhaphy. The topic-in-title articles in all journals with this type of surgery increased from five (1991-2000) to 49 (2001-2010). The increase in postherniorrhaphy pain reporting is in stark contrast to publications regarding other types of postsurgical pain, especially in surgical journals (Figure 2). 
Table 5 Time-related progress in numerical representation of topic-in-title articles on chronic pain after specific surgeries

\begin{tabular}{|c|c|c|c|c|c|c|c|}
\hline \multirow[t]{2}{*}{ No } & \multirow[t]{2}{*}{ Specific surgeries } & \multicolumn{3}{|c|}{ All journals } & \multicolumn{3}{|c|}{ Surgical journals ${ }^{\mathbf{a}}$} \\
\hline & & $8 I-90$ & $91-00$ & $01-10$ & $81-90$ & $91-00$ & $01-10$ \\
\hline I & Herniorrhaphy & 0 & 5 & 49 & 0 & 5 & 41 \\
\hline 2 & Limb amputation & 7 & 18 & 22 & 0 & 4 & 2 \\
\hline 3 & Thoracic surgery & 2 & 10 & 16 & 0 & 4 & 6 \\
\hline 4 & Arthroplasty & 6 & 4 & 11 & 2 & 2 & 6 \\
\hline 5 & Breast surgery & I & 5 & 9 & 0 & 0 & 0 \\
\hline 6 & Cardiac surgery & I & 4 & 8 & 0 & I & 0 \\
\hline 7 & Gallbladder surgery & 0 & 4 & I & 0 & I & 0 \\
\hline 8 & Prostatectomy & 0 & 0 & 3 & 0 & 0 & I \\
\hline
\end{tabular}

Note: ${ }^{a}$ Number of articles in all surgical journals covered by PubMed.

The most significant sign of insufficient representation of chronic postsurgical pain is found in the presentation of this topic in surgical textbooks (2008-2010 editions). The presentation of chronic postsurgical pain in less than a page for various groups of surgeries per 2000-3000 pages of a textbook is clearly inadequate. However, chronic pain after herniorrhaphy is reflected in all three surgical texts analyzed (mostly very briefly).

Over the 10 years since the publication of seminal papers presenting postsurgical chronic pain, ${ }^{4-6}$ an important change has occurred but only in one area: chronic pain after herniorrhaphy. TJSI for herniorrhaphy has reached $36.7 \%$ (Table 6). It means that approximately one-third of all articles on herniorrhaphy in all journals covered by PubMed were published in the top 20 surgical journals. TJSI represents the ratio of the number of articles in the top 20 journals of the specialty to the number of articles in all journals covered by PubMed ( $>5000)$. A surge of this index is the sign of rising interest in a publication topic. For some reason, the top journals respond more rapidly to new and important developments in a specialty. ${ }^{11,12,17}$ At a time when TJSI for chronic pain after herniorrhaphy was so high, it was ten times lower for seven other surgeries $(2.9 \%)$, reflecting insignificant attention to chronic pain after these types of surgeries. Hopefully, the increased TJSI for herniorrhaphy indicates the initial change in the attitude toward chronic postsurgical pain in general and that it will soon spread to other groups of surgeries.

Such a change in attitude is necessary because of the vast number of patients with chronic postsurgical pain. Macrae ${ }^{3}$ gave some insight into the magnitude of the problem by taking the number of operations performed in the US in 1994 (only for seven groups of surgeries) and multiplying it by the lowest figures for the incidence of chronic pain for these surgeries. His calculations yielded a possible 394,000 cases of chronic postsurgical pain each year. The complete absence of editorials related to this problem in the 1990-2000 period clearly indicates that the attention of the medical community was not focused on this type of pain.

The main reason for the neglect of chronic postsurgical pain in surgical journals and textbooks was well described by Macrae in 2001: "It is hard for any doctor to accept that the treatments they offer may cause morbidity, especially if they feel that they may be to blame. ${ }^{.4}$ An additional reason might be that surgeons are less exposed to patients with developed chronic postsurgical pain than physicians in other specialties (eg, family medicine, pain medicine, neurology). At the same time, surgeons do have good reasons to feel that they are not to be blamed for chronic postsurgical pain. Although iatrogenic neuropathic pain caused by intraoperative nerve injury is the most common type of chronic postsurgical pain, this type of pain may also happen without any damage to a nerve trunk. ${ }^{8,9}$ In addition, nerve damage alone is usually not sufficient to cause chronic pain, because most of the cases of intraoperative nerve damage result in motor and

Table 6 Top Journal Selectivity Index (TJSI) for representation of chronic pain as an adverse effect of surgery

\begin{tabular}{|c|c|c|c|c|}
\hline \multirow{2}{*}{$\begin{array}{l}\text { Topic of } \\
\text { publications }\end{array}$} & \multirow[t]{2}{*}{ Years } & \multicolumn{2}{|c|}{ Number of articles ${ }^{a}$} & \multirow{2}{*}{$\begin{array}{l}\text { TJSI } \\
\text { (ratio } \\
\text { of top } \\
\text { to all) }\end{array}$} \\
\hline & & $\begin{array}{l}\text { All } \\
\text { journals }^{b} \\
(>5000)\end{array}$ & $\begin{array}{l}\text { Top } \\
\text { specialty } \\
\text { journals }{ }^{c}(20)\end{array}$ & \\
\hline Chronic postsurgical & $91-00$ & 5 & 2 & \\
\hline pain: herniorrhaphy & $01-10$ & 49 & 18 & $36.7 \%$ \\
\hline Chronic postsurgical & $91-00$ & 45 & I & \\
\hline pain: seven specific & $01-10$ & 70 & 2 & $2.9 \%$ \\
\hline
\end{tabular}

surgeries $^{d}$

Notes: TJSI represents the number of articles published in the top 20 journals to the number of articles in all journals covered by PubMed; ${ }^{11,12}$ aTopic-in-title articles; bjournals covered by PubMed; 'top 20 surgical journals sorted by impact factor (journal citation report, 2010); dimb amputation, thoracic surgery, arthroplasty, breast surgery, cardiac surgery, gallbladder surgery, prostatectomy. 
Table 7 Presentation of chronic postsurgical pain in surgical textbooks

\begin{tabular}{|c|c|c|c|c|}
\hline & $\begin{array}{l}\text { Sabiston Textbook } \\
\text { of Surgery, } 2008\end{array}$ & $\begin{array}{l}\text { Schwartz's Principles } \\
\text { of Surgery, } 2009\end{array}$ & $\begin{array}{l}\text { Greenfield's } \\
\text { Surgery, } 2010\end{array}$ & $\begin{array}{l}\text { Miller's Anesthesia, } \\
2010\end{array}$ \\
\hline Total number of pages & 2286 & 1776 & 2074 & 3084 \\
\hline Total number of lines ${ }^{a}$ on the topic & 85 & 70 & 64 & 100 \\
\hline Total number of references on the topic & 4 & 2 & 5 & 12 \\
\hline \multicolumn{5}{|l|}{ Presence of the topic in chapters } \\
\hline Basic principles & + & + & - & + \\
\hline Limb amputation & - & - & + & - \\
\hline Thoracotomy & - & - & - & + \\
\hline Coronary artery bypass grafting & - & - & - & + \\
\hline Mastectomy & - & - & + & - \\
\hline Inguinal herniorrhaphy & + & + & + & - \\
\hline
\end{tabular}

Note: approximately 120 lines per page.

sensory changes without the development of chronic pain. Chronic postsurgical pain is complex and poorly understood; there are many possible factors in its development (see reviews ${ }^{3,8,9}$ ).

It is accepted that chronic postsurgical pain is an inevitable consequence of surgery in a certain proportion of cases, like wound infection. ${ }^{3}$ Chronic postsurgical pain should be discussed openly, and correct information on risk should be given to prospective patients. The incidence of chronic postsurgical pain varies very widely, up to $80 \%$ with limb amputations. ${ }^{18}$ The Stabiston Textbook of Surgery ${ }^{13}$ indicates that chronic pain after open inguinal hernia repair has incidence ranging from $29 \%$ to $75 \%$. A systematic review by Aasvang and Kehlet ${ }^{2}$ reported that the overall incidence of chronic pain after open inguinal herniorrhaphy is $18 \%$. In a recent large prospective study, Aasvang et a ${ }^{19}$ found that the incidence of substantial pain 6 months after groin hernia repair was $12 \%$. If patients had accurate information on their risk of chronic pain, they at least would be in the position to decide against an operation.

According to Kehlet et al, ${ }^{8}$ the analysis of all possible approaches for the prevention of chronic postsurgical pain yields only one reliable solution: to use surgical techniques that avoid nerve damage. In a subsequent study, ${ }^{19}$ these authors provided a rationale for selecting surgical techniques with a lower risk of chronic pain after groin hernia repair. They demonstrated that the incidence of "substantial pain" was significantly lower with laparoscopic than with open surgery $(8.1 \%$ vs $16.0 \%, P<0.02)$. A similar conclusion regarding chronic pain after laparoscopic versus open surgery was reached regarding cholecystectomy. Stiff et $\mathrm{al}^{20}$ indicated that right upper quadrant chronic pain was less common after laparoscopic surgery $(3.4 \%$ vs $9.7 \%$, $P<0.05)$.
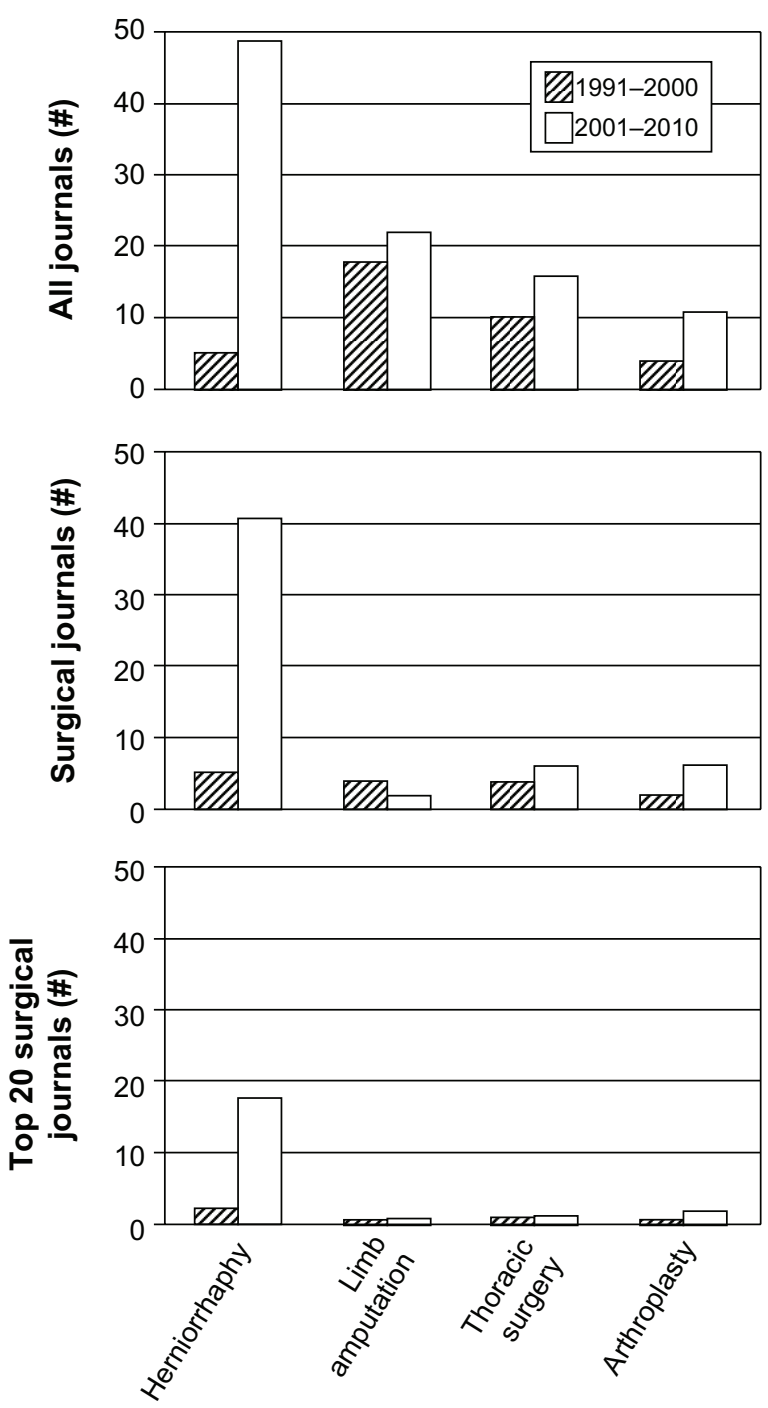

Figure 2 Number of topic-in-title articles published in |99|-2000 and 200I-20I0 periods on chronic pain after the four types of specific surgeries. ${ }^{a}$ Notes: aAlong the vertical axis, the number (\#) of articles published in all journals (including surgical journals), the number of articles published in surgical journals (including top 20 surgical journals), and the number of articles published in top 20 surgical journals (listed in the method section). Along the horizontal axis, the four types of specific surgeries with the highest number of published articles. 
Although chronic postsurgical pain is relevant to many specialties (eg, surgery, anesthesiology, neurology, pain medicine, and rehabilitation medicine), risk can be decreased only by surgeons, because only they can choose to use techniques with lower risk of nerve damage. Chronic postoperative pain can also include anesthesia-related nerve injuries. Cheney et $\mathrm{al}^{21}$ analyzed claims against anesthesiologists and found that $670(16 \%$ of 4183$)$ claims were for anesthesia-related nerve injury, including nerve injuries due to positioning of the patient after anesthesia induction. The most frequent sites of injury were the ulnar nerve $(28 \%)$ and brachial plexus $(20 \%)$.

\section{Conclusion}

In conclusion, chronic postsurgical pain is still insufficiently represented, especially in surgical journals and textbooks. However, there is an indication (rise in TJSI) that the interest in this topic began to increase. At present, the increase is mostly related to one specific group of surgeries: herniorrhaphy. However, it is likely that the change in the attitude toward chronic postsurgical pain will spread to other specific groups of surgeries.

\section{Disclosure}

The authors report no conflicts of interest in this work.

\section{References}

1. Pizzo PA, Clark NM. Alleviating suffering 101 - pain relief in the United States. N Engl J Med. 2012;366:197-199.

2. Aasvang E, Kehlet H. Surgical management of chronic pain after inguinal hernia repair. Br J Surg. 2005;92:795-801.

3. Macrae WA. Chronic post-surgical pain: 10 years on. Br J Anaesth. 2008;101:77-86.

4. Macrae WA. Chronic pain after surgery. Br J Anaesth. 2001;87:88-98.

5. Crombie IK, Davies HT, Macrae WA. Cut and thrust: antecedent surgery and trauma among patients attending a chronic pain clinic. Pain. 1998;76:167-171.

6. Perkins FM, Kehlet H. Chronic pain as an outcome of surgery. A review of predictive factors. Anesthesiology. 2000;93:1123-1133.

7. Dworkin RH, O'Connor AB, Backonja M, Farrar JT, Finnerup NB, Jensen TS, et al. Pharmacologic management of neuropathic pain: evidence-based recommendations. Pain. 2007;132:237-251.

8. Kehlet H, Jensen TS, Woolf CJ. Persistent postsurgical pain: risk factors and prevention. Lancet. 2006;367:1618-1625.

9. Katz J, Seltzer Z. Transition from acute to chronic postsurgical pain: risk factors and protective factors. Expert Rev Neurother. 2009;9:723-744.
10. Rabow MW, Hardie GE, Fair JM, McPhee SJ. End-of-life care content in 50 textbooks from multiple specialties. JAMA. 2000;283:771-778.

11. Kissin I. Can a bibliometric indicator predict the success of a drug? Scientometrics. 2011;86:785-795.

12. Kissin I, Bradley EL Jr. Top Journal Selectivity Index: is it acceptable for drugs beyond the field of analgesia? Scientometrics. 2011;88:589-597.

13. Townsend CM Jr, Beauchamp RD, Evers BM, Mattox KL. Sabiston Textbook of Surgery: The Biological Basis of Modern Surgical Practice. 18th ed. Philadelphia, PA: Saunders/Elsevier; 2008.

14. Brunicardi F, Andersen D, Billiar T, et al. Schwartz's Principles of Surgery. 9th ed. New York, NY: McGraw-Hill, Medical Pub Division; 2009.

15. Mulholland MW, Lillemoe KD, Doherty GM, Maier RV, Simeone DM, Upchurch GR. Greenfield's Surgery: Scientific Principles and Practice. 5th ed. Philadelphia, PA: Wolters Kluwer Health/Lippincot Williams \& Wilkins; 2010.

16. Miller RD, Eriksson LI, Fleisher LA, Weiner-Kronish JP. Miller's Anesthesia. 7th ed. Philadelphia, PA: Churchill Livingstone Elsevier; 2010.

17. Kissin I, Bradley EL Jr. Top Journal Selectivity Index and 'me-too' drugs. Scientometrics. 2012;91:131-142.

18. Sherman RA, Sherman CJ, Parker L. Chronic phantom and stump pain among American veterans: results of a survey. Pain. 1984;18: 83-95.

19. Aasvang EK, Gmaehle E, Hansen JB, Gmaehle B, Forman JL, Schwarz J, et al. Predictive risk factors for persistent postherniotomy pain. Anesthesiology. 2010;112:957-969.

20. Stiff G, Rhodes M, Kelly A, Telford K, Armstrong CP, Rees BI. Long-term pain: less common after laparoscopic than open cholecystectomy. Br J Surg. 1994;81:1368-1370.

21. Cheney FW, Domino KB, Caplan RA, Posner KL. Nerve injury associated with anesthesia: a closed claims analysis. Anesthesiology. 1999;90:1062-1069.

22. Macrae WA. Chronic pain after sternotomy. Acta Anaesthesiol Scand. 2001;45:927-928.

23. Gottschalk A, Raja SN. Severing the link between acute and chronic pain: the anesthesiologists role in preventive medicine. Anesthesiology. 2004;101:1083-1085.

24. Eisenach JC. Preventing chronic pain after surgery: who, how and when? Reg Anesth Pain Med. 2006;31:1-3.

25. Romundstad L, Stubhaug A. Glucocorticoids for acute and persistent postoperative neuropathic pain: what is the evidence? Anesthesiology. 2007;107:371-373.

26. Loftus LS, Laronga C. Evaluating patients with chronic pain after breast cancer surgery: the search for relief. JAMA. 2009;302:2034-2035.

27. De Kock M. Expanding our horizons: transition of acute postoperative pain to persistent pain and establishment of chronic postsurgical pain services. Anesthesiology. 2009;111:461-463.

28. Lavand'homme P. Chronic pain after vaginal and cesarean delivery: a reality questioning our daily practice of obstetric anesthesia. Int $J$ Obstet Anesth. 2010;19:1-2.

29. Rappaport BA, Cemy I, Sanhai WR. Action on the prevention of chronic pain after surgery: public-private partnerships, the future of analgesic drug development. Anesthesiology. 2010;112:509-510.

30. Enck RE. Postsurgical chronic pain. Am J Hosp Palliat Care. 2010;27:301-302. 


\section{Supplementary material}

List of "topic-in-title" articles on chronic postsurgical pain (1981-2010)

Aasvang E, Kehlet H. Surgical management of chronic pain after inguinal hernia repair. Br J Surg. 2005;92:795-801.

Aasvang EK, Bay-Neilsen M, Kehlet H. Pain and functional impairment 6 years after inguinal herniorrhaphy. Hernia. 2006;10:316-321.

Aasvang EK, Brandsborg B, Jensen TS, Kehlet H. Heterogeneous sensory processing in persistent postherniotomy pain. Pain. 2010;150:237-242.

Aasvang EK, Gmaehle E, Hansen JB, Gmaehle B, Forman JL, Schwarz J, et al. Predictive risk factors for persistent postherniotomy pain. Anesthesiology. 2010;112:957-969.

Aasvang EK, Jensen KE, Fiirgaard B, Kehlet H. MRI and pathology in persistent postherniotomy pain. JAm Coll Surg. 2009;208:1023-1028.

Aasvang EK, Kehlet H. Chronic pain after childhood groin hernia repair. J Pediatr Surg. 2007;42:1403-1408.

Aasvang EK, Kehlet H. The effect of mesh removal and selective neurectomy on persistent postherniotomy pain. Ann Surg. 2009;249:327-334.

Alfieri S, Rotondi F, Di Giorfio A, Fumagalli U, Salzano A, Di Miceli D, et al; Groin Pain Trial Group. Influence of preservation versus division of ilioinguinal, iliohypogastric, and genital nerves during open mesh herniorrhaphy: prospective multicentric study of chronic pain. Ann Surg. 2006;243:553-558.

Amid PK, Hiatt JR. New understanding of the cause and surgical treatment of postherniorrhaphy inguinodynia and orchalgia. J Am Coll Surg. 2007;205:381-385.

Asnis SE, Hanley S, Shelton PD. Sciatic neuropathy secondary to migration of trochanteric wire following total hip arthroplasty. Clin Orthop Relat Res. 1985;196: 226-228.

Bach S, Noreng MF, Tjellden NU. Phantom limb pain in amputees during the first 12 months following limb amputation, after preoperative lumbar epidural blockade. Pain. 1988;33:297-301.

Bay-Nielsen M, Perkins FM, Kehlet H. Pain and functional impairment 1 year after inguinal herniorrhaphy: a nationwide questionnaire study. Ann Surg. 2001;233:1-7.
Bisgaard T, Rosenberg J, Kehlet H. From acute to chronic pain after laparoscopic cholecystectomy: a prospective follow-up analysis. Scan J Gastroenterol. 2005;40: 1358-1364.

Bittner R, Gmähle E, Gmähle B, Schwarz J, Aasvang E, Kehlet $\mathrm{H}$. Lightweight mesh and noninvasive fixation: an effective concept for prevention of chronic pain with laparoscopic hernia repair(TAPP). Surg Endosc. 2010;24:2958-2964.

Bosmans JC, Suurmeijer TP, Hulsink M, van der Schans CP, Geertzen JH, Dijkstra PU. Amputation phantom pain and subjective well-being: a qualitative study. Int $J$ Rehabil Res. 2007;30:1-8.

Bower S, Moore BB, Weiss SM. Neuralgia after inguinal hernia repair. Am Surg. 1996;62:664-667.

Bozuk M, Schuster R, Stewart D, Hicks K, Greaney G, Waxman K. Disability and chronic pain after open mesh and laparoscopic inguinal hernia repair. Am Surg. 2003;69:839-841.

Brandsborg B, Nikolajsen L, Hansen CT, Kehlet H, Jensen TS. Risk factors for chronic pain after hysterectormy: a nationwide questionnaire and database study. Anesthesiology. 2007;106:1003-1012.

Bruce J, Drury N, Poobalan AS, Jeffrey RR, Smith WC, Chambers WA. The prevalence of chronic chest and leg pain following cardiac surgery: a historical cohort study. Pain . 2003;104:265-273.

Buvanendran A, Kroin JS, Della Valle CJ, Kari M, Moric M, Tuman KJ. Perioperative oral pregabalin reduces chronic pain after total knee arthroplasty: a prospective, randomized, controlled trial. Anesth Analg. 2010;110: 199-207.

Callesen T, Bech K, Kehlet H. Prospective study of chronic pain after groin hernia repair. Br J Surg. 1999;86:1528-1531.

Carle C, Ashworth A, Roscoe A. A survey of post-sternotomy chronic pain following cardiac surgery. Anaesthesia. 2009;64:1387.

Casscells CD, Lindsey RW, Ebersole J, Li B. Ulnar neuropathy after median sternotomy. Clin Orthop Relat Res. 1993;291:259-265.

Catchlove RF. Phantom pain following limb amputation in a paraplegic. A case report. Psychother Psychosom. 1983;39:89-93.

Chauhan BM, Kim DJ, Wainapel SF. Saphenous neuropathy following coronary artery bypass surgery. $N$ Y State J Med. 1981;81:222-223. 
Clarke H, Pereira S, Kennedy D, Andrion J, Mitsakakis N, Gollish J, et al. Adding gabapentin to a multimodal regimen does not reduce acute pain, opioid consumption or chronic pain after total hip arthroplasty. Acta Anaesthesiol Scand. 2009;53:1073-1083.

Conacher ID. Percutaneous cryotherapy for post-thoracotomy neuralgia. Pain. 1986;25:227-228.

Conacher ID. Therapists and therapies for post-thoracotomy neuralgia. Pain. 1992;48:409-412.

Courtney CA, Duffy K, Serpell MG, O’Dwyer PJ. Outcome of patients with severe chronic pain following repair of groin hernia. Br J Surg. 2002;89:1310-1314.

Crombie IK, Davies HT, Macrae WA. Cut and thrust: antecedent surgery and trauma among patients attending a chronic pain clinic. Pain. 1998;76:167-171.

Dajczman E, Gordon A, Kreisman H, Wolkove N. Long-term postthoracotomy pain. Chest. 1991;99:270-274.

De Kock M. Expanding our horizons: transition of acute postoperative pain to persistent pain and establishment of chronic postsurgical pain services. Anesthesiology. 2009;111:461-463.

deJonge P, Lloyd A, Horsfall L, Tan R, O’Dwyer PJ. The measurement of chronic pain and health-related quality of life following inguinal hernia repair: a review of the literature. Hernia. 2008;12:561-569.

Dennis R, O'Riordan D. Risk factors for chronic pain after inguinal hernia repair. Ann R Coll Surg Engl. 2007; 89:218-220.

Desmond DM, Maclachlan M. Prevalence and characteristics of phantom limb pain and residual limb pain in the long term after upper limb amputation. Int J Rehabil Res. 2010;33:279-282.

DeVita MA, Robinson LR, Rehder J, Hattler B, Cohen C. Incidence and natural history of phrenic neuropathy occurring during open heart surgery. Chest. 1993;103: $850-856$.

Dijkstra PU, Geertzen JH, Stewart R, van der Schans CP. Phantom pain and risk factors: a multivariate analysis. J Pain Symptom Manage. 2002;24:578-585.

Dijkstra PU, Reitman JS, Geertzen JH. Phantom breast sensations and phantom breast pain: a 2-year prospective study and methodological analysis of literature. Eur J Pain. 2007;11:99-108.
Dualé C, Sibaud F, Guastella V, Vallet L, Gimbert YA, Taheri H, et al. Perioperative ketamine does not prevent chronic pain after thoracotomy. Eur J Pain. 2009;13: 497-505.

Ducic I, Mesbahi AN, Attinger CE, Graw K. The role of peripheral nerve surgery in the treatment of chronic pain associated with amputation stumps. Plast Reconstru Surg. 2008;121:908-914.

Eggers KA, Asai T. Postoperative brachial plexus neuropathy after total knee replacement under spinal anaesthesia. $\mathrm{Br} J$ Anaesth. 1995;75:642-644.

Ehde DM, Czerniecki JM, Smith DG, et al. Chronic phantom sensations, phantom pain, residual limb pain, and other regional pain after lower limb amputation. Arch Phys Med Rehabil. 2000;81:1039-1044.

Eklund A, Montgomery A, Bergkvist L, Rudberg C; Swedish Multicentre Trial of Inguinal Hernia Repair by Laparoscopy (SMIL) study group. Chronic pain 5 years after randomized comparison of laparoscopic and Lichtenstein inguinal hernia repair. Br J Surg. 2010;97:600-608.

Ellis K. A review of amputation phantom pain and nursing responsibilities. Br J Nurs. 2002;11:155-157.

Erdek MA, Staats PS. Chronic pain and thoracic surgery. Thorac Surg Clin. 2005;15:123-130.

Erhan Y, Erhan E, Aydede H, Merean M, Tok D. Chronic pain after Lichtenstein and periotoneal (posterior) hernia repair. Can J Surg. 2008;51:383-387.

Fainsinger RL, deGara C, Perez GA. Amputation and the prevention of phantom pain. J Pain Symptom Manage. 2000;20:308-312.

FassoulakiA, Melemeni A, Staikou C, Triga A, Sarantopoulos C. Acute postoperative pain predicts chronic pain and long-term analgesic requirements after breast surgery for cancer. Acta Anaesthesiol Belg. 2008;59:241-248.

Fassoulaki A, Sarantopoulos C, Melemeni A, Hogan Q. EMLA reduces acute and chronic pain after breast surgery for cancer. Reg Anesth Pain Med. 2000;25:350-355.

Fassoulaki A, Triga A, Melemeni A, Sarantopoulos C. Multimodal analgesia with gabapentin and local anesthetics prevents acute and chronic pain after breast surgery for cancer. Anesth Analg. 2005;101:1427-1432.

Ferzli GS, Edwards ED, Khoury GE. Chronic pain after inguinal herniorrhaphy. J Am Coll Surg. 2007;205:333-341. 
Fischer SR, Christ DJ, Roehr BA. Sciatic neuropathy secondary to total hip arthroplasty wear debris. J Arthroplasty. 1999;14:771-774.

Fisher K, Hanspal RS. Phantom pain, anxiety, depression, and their relation in consecutive patients with amputated limbs: case reports. BMJ. 1998;316:903-904.

Flexman A, Ng J, Gelb A. Acute and chronic pain following craniotomy. Curr Opin Anaesthesiol. 2010;23:551-557.

Flor H, Birbaumer N. Phantom limb pain: cortical plasticity and novel therapeutic approaches. Curr Opin Anaesthesiol. 2000;13:561-564.

Flor H. Phantom-limb pain: characteristics, causes, and treatment. Lancet Neurol. 2002;1:182-189.

Fokter SK, Repse-Fokter A, Takac I. Case report: femoral neuropathy secondary to total hip arthroplasty wear debris. Clin Orthop Relat Res. 2009;467:3032-3035.

Franneby U, Gunnarsson U, Andersson M, et al. Validation of an inguinal pain questionnaire for assessment of chronic pain after groin hernia repair. Br J Surg. 2008;95: 488-493.

Franneby U, Sandblom G, Nordin P, Nyren O, Gunnarsson U. Risk factors for long-term pain after hernia surgery. Ann Surg. 2006;244:212-219.

Gallagher P, Allen D, Maclachlan M. Phantom limb pain and residual limb pain following lower limb amputation: a descriptive analysis. Disabil Rehabil. 2001;23:522-530.

Gerbershagen JH, Ozgur E, Dagtekin O, et al. Preoperative pain as a risk factor for chronic post-surgical pain - six month follow-up after radical prostatectomy. Eur J Pain. 2009. [Epub ahead of print.]

Gillion JF, Fagniez PL. Chronic pain and cutaneous sensory changes after inguinal hernia repair: comparison between open and laparoscopic techniques. Hernia. 1999;3: 75-80.

Gjeilo KH, Klepstad P, Wahba A, Lydersen S, Stenseth R. Chronic pain after cardiac surgery: a prospective study. Acta Anaesthesiol Scand. 2010;54:70-78.

Gotoda Y, Kambara N, Sakai T, et al. The morbidity, time course and predictive factors for persistent post-thoracotomy pain. Eur J Pain. 2001;5:89-96.

Gottschalk A, Ochroch EA. Clinical and demographic characteristics of patients with chronic pain after major thoracotomy. Clin J Pain. 2008;24:708-716.
Granot M. Can we predict persistent postoperative pain by testing preoperative experimental pain? Curr Opin Anaesthesiol. 2009;22:425-430.

Grant AM, Scott NW, O’Dwyer PJ. Five-year follow-up of a randomized trial to assess pain and numbness after laparoscopic or open repair or groin hernia. Br J Surg. 2004;91:1570-1574.

Grant P, Reise O, Ovre S. Obturator neuropathy due to intrapelvic extrusion of cement during total hip replacement report of 2 patients. Acta Orthop Scand. 2001;72:537-540.

Hanley MA, Jensen MP, Ehde DM, Hoffman AJ, Patterson DR, Robinson LR. Psychosocial predictors of long-term adjustment to lower-limb amputation and phantom limb pain. Disabil Rehabil. 2004;26:882-893.

Hanley MA, Jensen MP, Smith DG, et al. Preamputation pain and acute pain predict chronic pain after lower extremity amputation. J Pain. 2007;8:102-109.

Harden RN, Bruehl S, Stanos S, et al. Prospective examination of pain-related and psychological predictors of CRPS-like phenomena following total knee arthroplasty: a preliminary study. Pain. 2003;106:393-400.

Hardy PA. Post-thoracotomy intercostal neuralgia. Lancet. 1986;1:626-627.

Harvie P, Giele H, Fang C, et al. The treatment of femoral neuropathy due to pseudotumour caused by metal-on-metal resurfacing arthroplasty. Hip Int. 2008;18: 313-320.

Hassan I, Jacobs AG, Baig ME, Van der Meyden $\mathrm{CH}$. Bilateral axillary and suprascapular neuropathy after coronary artery bypass surgery. Cardiovasc $J$ S Afr. 2006;17: 259-261.

Hayes C, Armstrong-Brown A, Burstal R. Perioperative intravenous ketamine infusion for the prevention of persistent post-amputation pain: A randomized, controlled trial. Anaesth Intensive Care. 2004;32:330-338.

Hazelrigg SR, Cetindag IB, Fullerton J. Acute and chronic pain syndromes after thoracic surgery. Surg Clin North Am. 2002;82:849-865.

Hill A. Phantom limb pain: a review of the literature on attributes and potential mechanisms. J Pain Symptom Manage. 1999; 17:125-142.

Hinricha-Rocker A, Schulz K, Jarvinen I, et al. Psychosocial predictors and correlates for chronic postsurgical pain (CPSP): a systematic review. Eur J Pain. 2009;13:719-730. 
Hompes R, Vansteenkiste F, Pottel H, Devriendt D, Van Rooy F. Chronic pain after Kugel inguinal hernia repair. Hernia. 2008;12:127-132.

Houghton AD, Saadah E, Nicholls G, McColl L, Houghton AL. Phantom pain: natural history and association with rehabilitation. Ann R Coll Surg Engl. 1994;76:22-25.

Huse E, Larbig W, Birbaumer N, Flor H. Cortical reorganization and pain: empirical findings and therapeutic implication using example of phantom pain. Schmerz. 2001;15:131-137.

Huse E, Larbig W, Flor H, Birbaumer N. The effect of opioids on phantom limb pain and cortical reorganization. Pain. 2001;90:47-55.

Huse E, Preissl H, Larbig W, Birbaumer N. Phantom limb pain. Lancet. 2001;358:1015.

Iacono RP, Sandyk R, Bamford CR, Awerbuch G, Malone JM. Post-amputation phantom pain and autonomous stump movements responsive to doxepin. Funct Neurol. 1987;2:343-348.

Iohom G, Abdalla H, O'Brien J, et al. The associations between severity of early postoperative pain, chronic postsurgical pain and plasma concentration of stable nitric oxide products after breast surgery. Anesth Analg. 2006;103:995-1000.

Jahangiri M, Jayatunga AP, Bradley JW, Dark CH. Prevention of phantom pain after major lower limb amputation by epidural infusion of diamorphine, clonidine and bupivacaine. Ann R Coll Surg Engl. 1994;76:324-326.

Jensen TS, Krebs B, Neilsen J, Rasmussen P. Immediate and long-term phantom limb pain in amputees: incidence, clinical characteristics and relationship to pre-amputation limb pain. Pain. 1985;21:267-268.

Jensen TS, Krebs B, Nielsen J, Rasmussen P. Phantom limb, phantom pain and stump pain in amputees during the first 6 months following limb amputation. Pain. $1983 ; 17: 243-256$.

Jess P, Jess T, Beck H, Bech P. Neuroticism in relation to recovery and persisting pain after laparoscopic cholecystectomy. Scand J Gastroenterol. 1998;33:550-553.

Jorgensen T, Teglbjerg JS, Wille-Jorgensen P, Bille T, Thorvaldsen P. Persisting pain after cholecystectomy. A prospective investigation. Scand J Gastroenterol. 1991;26: $124-128$.
Kairaluoma PM, Bachmann MS, Rosenberg PH, Pere PJ. Preincisional paravertebral block reduces the prevalence of chronic pain after breast surgery. Anesth Analg. 2006;103:703-708.

Kalliomäki ML, Meyerson J, Gunnarsson U, Gordh T, Sandblom G. Long-term pain after inguinal hernia repair in a population-based cohort; risk factors and interference with daily activities. Eur J Pain. 2008;12:214-225.

Kalso E, Mennander S, Tasmuth T, Nilsson E. Chronic post-sternotomy pain. Acta Anaesthesiol Scand. 2001;45: 935-939.

Katz J. Phantom limb pain. Lancet. 1997;350: 1338-1339.

Katz J. Prevention of phantom limb pain by regional anaesthesia. Lancet. 1997;349:519-520.

Katz J, Asmundson GJ, McRae K, Halket E. Emotional numbing and pain intensity predict the development of pain disability up to one year after lateral thoracotomy. Eur J Pain. 2009;13:870-878.

Katz J, Cohen L. Preventive analgesia is associated with reduced pain disability 3 weeks but not 6 months after major gynecologic surgery by laparotomy. Anesthesiology. 2004;101:169-174.

Katz J, Jackson M, Kavanagh BP, Sandler AN. Acute pain after thoracic surgery predicts long-term post-thoracotomy pain. Clin J Pain. 1996;12:50-55.

Katz J, Melzack R. Pain 'memories' in phantom limbs: review and clinical observations. Pain. 1990;43:319-336.

Katz J, Seltzer Z. Transition from acute to chronic postsurgical pain: risk factors and protective factors. Expert Rev Neurother. 2009;9:723-744.

Katz J, Schmid R, Snijdelaar DG, Coderre TJ, McCartney CJ, Wowk A. Pre-emptive analgesia using intravenous fentanyl plus low-dose ketamine for radical prostatectomy under general anesthesia does not produce short-term or long-term reductions in pain or analgesic use. Pain. 2004;110:707-718.

Kehlet H, Jensen TS, Woolf CJ. Persistent postsurgical pain: risk factors and prevention. Lancet. 2006;367:1618-1625.

Kehlet H. Chronic pain after groin hernia repair. Br J Surg. 2008;95:135-136.

Keller JE, Stefanidis D, Dolce CJ, Iannitti DA, Kercher KW, Heniford BT. Combined open and laparoscopic approach 
to chronic pain after inguinal hernia repair. Am Surg. 2008;74:695-700.

Keller SM, Carp NZ, Levy MN, Rosen SM. Chronic post thoracotomy pain. J Cardiovasc Surg. 1994;35:161-164.

Kempster P, Gates P, Byrne E, Wilson A. Painful sciatic neuropathy following cardiac surgery. Aust $N Z \mathrm{~J} \mathrm{Med.}$ 1991;21:732-735.

Köninger J, Redecke J, Butters M. Chronic pain after hernia repair: a randomized trial comparing Shouldice, Lichtenstein and TAPP. Langenbecks Arch Surg. 2004;389:361-365.

Krane EJ, Keller LB. The prevalence of phantom limb sensation and pain pediatric amputees. J Pain Symptom Manage. 1995;10:21-29.

Kristensen AD, Pedersen TA, Hjortdal VE, Jensen TS, Nikolajsen L. Chronic pain in adults after thoracotomy in childhood or youth. Br J Anaesth. 2010;104:75-79.

Kroner K, Krebs B, Skov J, Jorgensen HS. Immediate and long-term phantom breast syndrome after mastectomy: incidence, clinical characteristics and relationship to premastectomy breast pain. Pain. 1989;36:327-334.

Lambert A, Dashfield A, Cosgrove C, et al. Randomized prospective study comparing preoperative epidural and intraoperative perineural analgesia for the prevention of postoperative stump and phantom limb pain following major amputation. Reg Anesth Pain Med. 2001;26:316-321.

Landreneau RJ, Mack MJ, Hazelrigg SR, Naunheim K, Dowling RD, Ritter P, et al. Prevalence of chronic pain after pulmonary resection by thoracotomy or video-assisted thoracic surgery. J Thorac Cardiovasc Surg. 1994;107: 1079-1085.

Lau H, Patil NG, Yuen WK, Lee F. Prevalence and severity of chronic groin pain after endoscopic totally extraperitoneal inguinal hernioplasty. Surg Endosc. 2003;17: 1620-1623.

Lautenbacher S, Huber C, Schofer D, Kunz M, Parthum A, Weber PG, et al. Attentional and emotional mechanisms related to pain as predictors of chronic postoperative pain: a comparison with other psychological and physiological predictors. Pain. 2010;151:722-731.

Lavand'homme P, De Kock M. The use of intraoperative epidural or spinal analgesia modulates postoperative hyperalgesia and reduces residual pain after major abdominal surgery. Acta Anaesthesiol Belg. 2008;57:373-379.
Leslie TA, Illing RO, Cranston DW, Guillebaud J. The incidence of chronic scrotal pain after vasectomy: a prospective audit. BJU Int. 2007;100:1330-1333.

Loftus LS, Laronga C. Evaluating patients with chronic pain after breast cancer surgery: the search for relief. JAMA. 2009;302:2034-2035.

Loos MJ, Scheltinga MR, Mulders LG, Roumen RM. The Pfannensteil incision as a source of chronic pain. Obstet Gynecol. 2008;111:839-846.

Loos MJ, Verhagen T, Scheltinga MR, Roumen RM. A randomised controlled trial of injection therapy versus neurectomy for post-herniorrhaphy inguinal neuralgia: rationale and study design. Hernia. 2010;14:593-597.

Lundblad H, Kreicbergs A, Jansson KA. Prediction of persistent pain after total knee replacement for osteoarthritis. $J$ Bone Joint Surg Br. 2008;90:166-171.

Macrae WA. Chronic pain after sternotomy. Acta Anaesthesiol Scand. 2001;45:927-928.

Macrae WA. Chronic pain after surgery. Br J Anaesth. 2001;87:88-98.

Macrae WA. Chronic post-surgical pain: 10 years on. $\mathrm{Br} J$ Anaesth. 2008;101:77-86.

Maguire MF, Latter JA, Mahajan R, Beggs D, Duffy JP. A study exploring the role of intercostal nerve damage in chronic pain after thoracic surgery. Eur J Cardiothorac Surg. 2006;29:873-879.

Maguire MF, Ravenscroft A, Beggs D, Duffy JP. A questionnaire study investigating the prevalence of the neuropathic component of chronic pain after thoracic surgery. Eur $J$ Cardiothorac Surg. 2006;29:800-805.

Manikandan R, Srirangam SJ, Pearson E, Collins GN. Early and late morbidity after vasectomy: a comparison of chronic scrotal pain at 1 and 10 years. BJU Int. 2004;93: 571-574.

Manny TB, Gorbachinsky I, Hemal AK. Lower extremity neuropathy after robot assisted laparoscopic radical prostatectomy and radical cystectomy. Can J Urol. 2010;17: 5390-5393.

Mazzoleni R, Vokaer M, Mavroudakis N, Bartholomé EJ, Bier JC. Antiphospholipid antibodies and ischemic neuropathy following cardiac surgery. Acta Neurol Belg. 2003;103: $176-178$. 
McMahon AJ, Buckley J, Taylor A, Lloyd SN, Dean RF, Kirk D. Chronic testicular pain following vasectomy. $\mathrm{Br} J$ Urol. 1992;69:188-191.

Melamed NB, Stya-Murti S. Obturator neuropathy after total hip replacement. Ann Neurol. 1983;13:578-579.

Meyerson J, Thelin S, Gordh T, Karlsten R. The incidence of chronic post-sternotomy pain after cardiac surgery - a prospective study. Acta Anaesthesiol Scand. 2001;45:940-944.

Mikkelsen T, Werner MU, Lassen B, Kehlet H. Pain and sensory dysfunction 6 to 12 months after inguinal herniotomy. Anesth Analg. 2004;99:146-151.

Miles J. Prevention of phantom pain after major lower limb amputation by epidural infusion of diamorphine, clonidine and bupivacaine. Ann R Coll Surg Engl. 1995;77:71.

Modirian E, Shojaei H, Soroush MR, Masoumi M. Phantom pain in bilateral upper limb amputation. Disabil Rehabil. 2009;31:1878-1881.

Mulvey MR, Bagnall AM, Johnson MI, Marchant PR. Transcutaneous electrical nerve stimulation (TENS) for phantom pain and stump pain following amputation in adults. Cochrane Database Syst Rev. 2010;12:CD007264.

Myers MA, Harmon RL. Sacral plexopathy and sciatic neuropathy after total knee arthroplasty. Electromyogr Clin Neurophysiol. 1998;38:423-426.

Nienhuijs S, Staal E, Strobbe L, Rosman C, Groenewoud H, Bleichrodt R. Chronic pain after mesh repair of inguinal hernia: a systemative review. Am J Surg. 2007;194: 394-400.

Nikolajsen L, Brandsborg B, Lucht U, Jensen TS, Kehlet H. Chronic pain following total hip arthroplasty: a nationwide questionnaire study. Acta Anaesthesiol Scand. 2006;50:495-500.

Nikolajsen L, Ilkjaer S, Christensen JH, Kroner K, Jensen TS. Randomised trial of epidural bupivacaine and morphine in prevention of stump and phantom pain in lower-limb amputation. Lancet. 1997;350(9088):1353-1357.

Nikolajsen L, Ilkjaer S, Kroner K, Christensen JH, Jensen TS. The influence of preamputation pain on postamputation stump and phantom pain. Pain. 1997;72:393-405.

Nikolajsen L, Kristensen AD, Thillemann TM, et al. Pain and somatosensory findings in patients 3 years after total hip arthroplasty. Eur J Pain. 2009;13:576-581.
Nikolajsen L, Sorensen HC, Jensen TS, Kehlet H. Chronic pain following Caesarean section. Acta Anaesthesiol Scand. 2004;48:111-116.

Nunchuck S, Keenan RJ, Ferson PF. Prevalence of chronic pain after pulmonary resection by thoracotomy or videoassisted thoracic surgery. J Thorac Cardiovasc Surg. 1994;107:1079-1085.

O’Dwyer PJ, Kingsnorth AN, Molloy RG, Small PK, Lammers B, Horeyseck G. Randomized clinical trial assessing impact of a lightweight or heavyweight mesh on chronic pain after inguinal hernia repair. Br J Surg. 2005;92:166-167.

Obata H, Salto S, Fujita N, Fuse Y, Ishizaki K, Goto F. Epidural block with mepivacaine before surgery reduces long-term post-thoracotomy pain. Can J Anaesth. 1999;46: 1127-1132.

Oberg E, Jacobsen B, Rosenberg J. Chronic pain and recurrence after laparoscopic inguinal herniorrhaphy. Surg Laparosc Endosc Percutan Tech. 2005;15:267-269.

Ochroch EA, Gottschalk A, Augostides J, et al. Longterm pain and activity during recovery from major thoracotomy using thoracic epidural analgesia. Anesthesiology. 2002;97:1234-1244.

Paajanen H. A single-surgeon randomized trial comparing three composite meshes on chronic pain after Lichtenstein hernia repair in local anesthesia. Hernia. 2007;11: 335-339.

Paily A, Thornton M. Chronic pain following a Lichtenstein inguinal hernia repair: a clinical and legal dilemma. ANZ J Surg. 2009;79:517-520.

Perttunen K, Tasmuth T, Kalso E. Chronic pain after thoracic surgery: a follow-up study. Acta Anaesthesiol Scan. 1999;43:563-567.

Pess GM, Lusskin R, Waugh TR, Battista AE. Femoral neuropathy secondary to pressurized cement in total hip replacement: treatment by decompression and neurolysis. Report of a case. J Bone Joint Surg Am. 1987;69:623-625.

Pinzur MS. Sciatic nerve block for residual limb pain following below-knee amputation. Contemp Orthop. 1991;22:290-292.

Pluijms WA, Steegers MA, Verhagaen AF, Scheffer GJ, Wilder-Smith OH. Chronic post-thoracotomy pain: 
a retrospective study. Acta Anaesthesiol Scan. 2006;50: 804-808.

Poleshuck EL, Katz J, Andrus CH, et al. Risk factors for chronic pain following breast cancer surgery: a prospective study. J Pain. 2006;7:626-634.

Poobalan AS, Bruce J, King PM, Chambers WA, Krukowski ZH, Smith WC. Chronic pain and quality of life following open inguinal hernia repair. Br J Surg. 2001;88: 1122-1126.

Poobalan AS, Bruce J, Smith WC, King PM, Krukowski ZH, Chambers WA. A review of chronic pain after inguinal herniorrhaphy. Clin J Pain. 2003;19:48-54.

Porter SS, Black DL, Rechling FW, Mason J. Intraoperative cortical somatosensory evoked potentials for detection of sciatic neuropathy during total hip arthroplasty. J Clin Anesth. 1989;1:170-176.

Rho RH, Lamer TJ, Fulmer JT. Treatment of genitofemoral neuralgia after laparoscopic inguinal herniorrhaphy with fluoroscopically guided tack injection. Pain Med. 2001;2:230-233.

Richardson C, Glenn S, Horgan M, Nurmikko T. A prospective study of factors associated with the presence of phantom limb pain six months after major lower limb amputation in patients with peripheral vascular disease. $J$ Pain. 2007;8:793-801.

Richardson C, Glenn S, Nurmikko T, Horgan M. Incidence of phantom phenomena including phantom limb pain 6 months after major lower limb amputation in patients with peripheral vascular disease. Clin J Pain. 2006;22: 353-358.

Richardson J, Sabanathan S, Mearns AJ, Sides C, Goulden CP. Post-thoracotomy neuralgia. Pain Clin. 1994;7: 87-97.

Richardson J. Chronic pain after thoracic surgery. Acta Anaesthesiol. Scand. 2000;44:220.

Romundstad L, Breivik H, Roald H, et al. Chronic pain and sensory changes after augmentation mammoplasty: long term effects of preincisional administration of methylprednisolone. Pain. 2006;124:92-99.

Rosen MJ, Novitsky YW, Cobb WS, Kercher KW, Heniford BT. Combined open and laparoscopic approach to chronic pain following open inguinal hernia repair. Hernia. 2006;10:20-24.
Rozen D, Ahn J. Pulsed radiofrequency for the treatment of ilioinguinal neuralgia after inguinal herniorrhaphy. Mt Sinai J Med. 2006;73:716-718.

Schley MN, Topofner S, Weich K, et al. Continuous brachial plexus blockade in combination with the NMDA receptor antagonist-memantine prevents phantom pain in acute traumatic upper limb amputees. Eur J Pain. 2007;11: 299-308.

Schwab R, Willms A, Kroger A, Becker HP. Less chronic pain following mesh fixation using a fibrin sealant in TEP inguinal hernia repair. Hernia. 2006;10:272-277.

Searle RD, Simpson MP, Simpson KH, Milton R, Bennett MI. Can chronic neuropathic pain following thoracic surgery be predicted during the postoperative period? Interact Cardiovasc Thorac Surg. 2009;9:999-1002.

Seid AS, Amos E. Entrapment neuropathy in laparoscopic herniorrhaphy. Surg Endosc. 1994;8:1050-1053.

Sen H, Sizlan A, Yanarates O, Senol MG, Inangil G, Sücüllü I, et al. The effects of gabapentin on acute and chronic pain after inguinal herniorrhaphy. Eur J Anaesthesiol. 2009;26:772-776.

Senturk M, Ozcan PE, Talu GK, et al. The effects of three different analgesia techniques on long-term postthoracotomy pain. Anesth Analg. 2002;94:11-15.

Sheridan PH Jr, Cheriyan A, Doud J, Dornseif SE, Montoya A, Houck J, et al. Incidence of phrenic neuropathy after isolated lung transplantation. The Loyola University Lung Transplant Group. J Heart Lung Transplant. 1995;14: 684-691.

Sherman RA, Sherman CJ, Parker L. Chronic phantom and stump pain among American veterans: results of a survey. Pain. 1984;18:83-95.

Simmons C Jr, Izant TH, Rothman RH, Booth RE Jr, Balderston RA. Femoral neuropathy following total hip arthroplasty. Anatomic study, case reports and literature review. J Arthroplasty. 1991;6:557-566.

Singh K, Phillips FM, Kuo E, Campbell M. A prospective, randomized double-blind study of the efficacy of postoperative continuous local anesthetic infusion at the iliac crest bone graft site after posterior spinal arthrodesis: a minimum of 4-year follow-up. Spine. 2007;32: 2790-2796.

Skandalakis JE, Skandalakis LJ, Colborn GL. Testicular atrophy and neuropathy in herniorrhaphy. Am Surg. 1996;62:775-782. 
Smeds S, Kald A, Löfström L. Chronic pain after open inguinal hernia repair: a longitudinal self-assessment study. Hernia. 2010;14:249-252.

Smith DG, Ehde DM, Hanley MA, et al. Efficacy of gabapentin in treating chronic phantom limb and residual limb pain. J Rehabil Res Dev. 2005;42:645-654.

Smith DG, Ehde DM, Legro MW, Reiber GE, del Aguila M, Boone DA. Phantom pain, residual limb, and back pain after lower extremity amputations. Clin Orthoped Relat Res. 1999;361:29-38.

Smith J, Thompson JM. Phantom limb pain and chemotherapy in pediatric amputees. Mayo Clinic Proc. 1995;70: 357-364.

Smith WCS, Bourne D, Squair J, Phillips DO, Chambers WA. A retrospective cohort study of post mastectomy pain syndrome. Pain. 1999;83:91-95.

Solak O, Metin M, Esme H, et al. Effectiveness of gabapentin in the treatment of chronic post-thoracotomy pain. Eur $J$ Cardiothorac Surg. 2007;32:9-12.

Staerkle RF, Buchli C, Villiger P. Patient satisfaction, hernia recurrence rate, and chronic pain. 10 years after endoscopic total extraperitoneal inguinal hernia repair. Surg Laparosc Endosc Percutan Tech. 2009;19:405-409.

Steegers MA, Snik DM, Verhagen AF, van der Drift MA, Wilder-Smith OH. Only half of the chronic pain after thoracic surgery shows a neuropathic component. J Pain. 2008;9:955-961.

Stevens PE, Dibble SL, Miaskowski C. Prevalence, characteristics, and impact of postmastectomy pain syndrome: an investigation of women's experiences. Pain. 1995;61:61-68.

Stiff G, Rhodes M, Kelly A, Telford K, Armstrong CP, Rees BI. Long-term pain: Less common after laparoscopic than open cholecystectomy. Br J Surg. 1994;81:1368-1370.

Stremmel C, Horn C, Eder S, Dimmler A, Lang W. The impact of immunological parameters on the development of phantom pain after major amputation. Eur J Vasc Endovasc Surg. 2005;30:79-82.

Swanson AJG. The incidence of prepatellar neuropathy following medial meniscectomy. Clin Orthop Rel Res. 1983;181:151-153.

Swenson JD, Bull DA. Postoperative ulnar neuropathy associated with prolonged ischemia in the upper extremity during coronary artery bypass surgery. Anesth Analg. 1997;85:1275-1277.

Tani Y, Miyawaki H. Femoral neuropathy caused by reinforcement ring malposition and extruded bone-cement after revision total hip arthroplasty. J Arthroplasty. 2002; 17:516-518.

Tasmuth T, Kataja M, Blomqvist C, von Smitten K, Kalso E. Treatment-related factors predisposing to chronic pain in patients with breast cancer - a multivariate approach. Acta Oncol. 1997;36:625-630.

Tasmuth T, von Smitten K, Kalso E. Pain and other symptoms during first year after radical and conservative surgery for breast cancer. Br J Cancer. 1996;74:2024-2031.

van Hanswijck de Jonge P, Lloyd A, Horsfall L, Tan R, O'Dwyer PJ. The measurement of chronic pain and health-related quality of life following inguinal hernia repair: a review of the literature. Hernia. 2008;12: 561-569.

van Veen RN, Wijsmuller AR, Vrijland WW, Hop WC, Lange JF, Jeekel J. Randomized clinical trial of mesh versus non-mesh primary inguinal hernia repair: long-term chronic pain at 10 years. Surgery. 2007;142:695-698.

Vik H, Andersen KJ, Julshamn K, Todnem K. Neuropathy caused by silver absorption from arthroplasty cement. Lancet. 1985;8433:872.

Vilholm OJ, Cold S, Rasmussen L, Sindrup SH. The postmastectomy pain syndrome: an epidemiological study on the prevalence of chronic pain after surgery for breast cancer. Br J Cancer. 2008;99:604-610.

Visser E. Chronic postsurgical pain: epidemiology and clinical implications for acute pain management. Acute Pain. 2006;8:73-81.

Vuilleumier H, Hübner M, Demartines N. Neuropathy after herniorrhaphy: indication for surgical treatment and outcome. World J Surg. 2009;33:841-845.

Wang J, Singh A, Higgins L, Warner J. Suprascapular neuropathy secondary to reverse shoulder arthroplasty: a case report. J Shoulder Elbow Surg. 2010;19:e5-e8.

Wartan SW, Hamann W, Wedley JR, McColl I. Phantom pain and sensation among British veteran amputees. Br J Anaesth. 1997;78:652-659.

Wassenaar EB, Raymakers JT, Rakic S. Removal of transabdominal sutures for chronic pain after laparoscopic ventral 
and incisional hernia repair. Surg Laparosc Endosc Percutan Tech. 2007;17:514-516.

Weiss SA, Lindell B. Phantom limb pain and etiology of amputation in unilateral lower extremity amputees. J Pain Symptom Manage. 1996;11:3-17.

Wicksell RK, Olsson GL. Predicting and preventing chronic postsurgical pain and disability. Anesthesiology. 2010;113:1260-1281.

Wijsmuller AR, Lange JFM, van Geldere D, Simons MP, Kleinrensink GJ, Hop WC, et al. Surgical techniques preventing chronic pain after Lichtenstein hernia repair: state-of-the-arts daily practice in the Netherlands. Hernia. 2007;11:147-151.

Wilder-Smith OH, Schreyer T, Scheffer GJ, Arendt-Neilsen L. Patients with chronic pain after abdominal surgery show less preoperative endogenous pain inhibition and more postoperative hyperalgesia: a pilot study. J Pain Palliat Care Pharmacother. 2010;24:119-128.

Wildgaard K, Iversen M, Kehet H. Chronic pain after lung transplantation: a nationwide study. Clin J Pain. 2010;26:217-222.

Wilson JA, Nimmo AF, Fleetwood-Walker SM, Colvin LA. A randomised double blind trial of the effect of pre-emptive epidural ketamine on persistent pain after lower limb amputation. Pain. 2008;135:108-118.

Wright D, Paterson C, Scott N, Hair A, O’Dwyer PJ. Fiveyear follow-up of patients undergoing laparoscopic or open groin hernia repair: a randomized controlled trial. Ann Surg. 2002;235:333-337.

Yarnitsky D, Cripsel Y, Eisenberg E, et al. Prediction of chronic post-operative pain: pre-operative DNIC testing identifies patients at risk. Pain. 2008;138:22-28.
Journal of Pain Research

\section{Publish your work in this journal}

The Journal of Pain Research is an international, peer-reviewed, open access, online journal that welcomes laboratory and clinical findings in the fields of pain research and the prevention and management of pain. Original research, reviews, symposium reports, hypothesis formation and commentaries are all considered for publication.

\section{Dovepress}

The manuscript management system is completely online and includes a very quick and fair peer-review system, which is all easy to use. Visit http://www.dovepress.com/testimonials.php to read real quotes from published authors. 